\title{
LOCAL ECOLOGICAL KNOWLEDGE IN ANGKLUNG PAGLAK OF USING COMMUNITY OF BANYUWANGI, INDONESIA
}

\author{
UTOMO, A. P. ${ }^{12^{*}}-$ AL MUHDHAR, M. H. I. ${ }^{1}-$ SYAMSURI, I. ${ }^{1}$ - INDRIWATI, S. E. ${ }^{1}$ \\ ${ }^{1}$ Biology Education Program, Universitas Negeri Malang \\ Jl. Semarang No. 5, Malang, Indonesia \\ ${ }^{2}$ Biology Education Program, Universitas Muhammadiyah Jember \\ Jl. Karimata No. 49, Jember, Indonesia \\ *Corresponding author \\ e-mail: agusprasetyo@unmuhjember.ac.id; phone: +62-331-336728; fax: +62-331-337957 \\ (Received $10^{\text {th }}$ Feb 2018; accepted $10^{\text {th }}$ May 2018)
}

\begin{abstract}
Angklung paglak is a traditional musical instrument made of bamboo of Using (an ethnic community of Banyuwangi). This study was conducted to reveal the Local Ecological Knowledge (LEK) in angklung paglak manufacturing and its correlation to bamboo conservation. The data collecting was done through documentation, participant observations, and interviews. For ensuring the validity and reliability of the data, cross-referenced and repeated information methods were used. The local knowledge in angklung making includes selecting benel (Gigantochloa atter) and ori (Bambusa arundinacea) as angklung materials, the age of the bamboo (more than three years old), the best month for logging since August to October, and the air drying the bamboo without exposing it to the direct sunlight in upright position. The belief includes logging on a particular day and a taboo for logging in December to February (sprouting period). Meanwhile, the local practice is reflected in the selective felling. The LEK found in the study- knowledge, belief and practice, contributes to the bamboo preservation. The whole process of angklung making teaches people to preserve and to live with nature, which reflects an ecological human characteristic. The perseverance and the ecological awareness are the keys to make a high-quality angklung paglak.
\end{abstract}

Keywords: ethnoecology, musical instrument, bamboo conservation, local wisdom, bamboo management

\section{Introduction}

Local people play an important role in conserving and managing natural resources as well as environment (Chaiphar, et al., 2013). Their interaction with nature has influenced the way of thinking, behaving, expressing and appreciating their culture (Keraf, 2002). Local people develop a system of local knowledge as a representative of the adaptation processes to their environment, including knowledge, belief, tradition, practices, and view of life (Vandebroek et al., 2011). Local knowledge can be unique because it differs in each community or country (Jasmine et al., 2016). The accumulation of knowledge, practices, and belief in the relationship of living things (including human) and environment is defined as Local Ecological Knowledge (LEK) (Berkes et al., 2000). LEK itself has contributed to the biodiversity conservation through ecosystem management and sustainable biodiversity which are experienced by local people. The persistent practices of natural resources by the local people are the basic knowledge of a complex ecological system (Gadgil et al., 1993).

Most Using (also Osing, an ethnic community of Banyuwangi in East Java Indonesia) are farmers for which the rice fields are their main resource and valuable property. The agricultural tradition that has been created by them is then passed to the next generation and is still being practiced by today's Using people. Anthropologically, 
culture is defined as human's creations which are obtained by acquiring or learning (Koentjaraningrat, 2015). One of the agricultural cultures of the Using people is a musical instrument called Angklung Paglak. This instrument is made of bamboo and played at the harvest time. The aim of playing it is to tell people that one's rice is about to be harvested. It also motivates the workers. The term paglak is derived from the name of a hut used by Using farmers to rest and oversee the field. People usually play the angklung in this paglak (Saputro et al., 2015); its height is 5-10 meters so that the sound can be heard by people around. The angklung players stand on the paglak and they will climb to it through the stairs of a single bamboo culm in which each internode is equipped with a bar for footing.

The angklung manufacture requires special knowledge and skill to produce a set of a melodious one. A set of angklung paglak consists of two pieces, each is made of 13-15 bamboo tubes (13-15 tones). The makers exceptionally pay attention to the quality; even they select the bamboo culm carefully. The tubes must be unbreakable and the tone must be stable. The belief in specific days and months to log bamboo trees also becomes the consideration in manufacturing to this day.

LEK can be learnt through holistic approach by using ethnoecology study. This approach analyzes how LEK, the history, the social and ecological function, as well as the relation to other dominant cultures are obtained in the local society (Ruiz-Mallén et al., 2012). Ethnoecology is a study of knowledge and management of the local people which is related to the ecological interactions (Martin, 2001). The purpose of the present study was to reveal the LEK of Using people in making angklung paglak through an ethnoecology study. The LEK covers knowledge, belief, practices of managing bamboo during the process of angklung manufacture which leads to bamboo conservation.

\section{Methodology}

Banyuwangi is a region in East Java Province, Indonesia. It is located at $7^{\circ} 43^{\prime}-8^{\circ} 46^{\prime}$ South latitude and $113^{\circ} 53^{\prime}-1^{\circ} 38$ East longitude (Badan Pusat Statistik Kabupaten Banyuwangi, 2015). Banyuwangi is a province located in the eastern area of East Java (Fig.1). This study was conducted in Glagah, Banyuwangi, specifically in three villages, namely Kemiren, Glagah, and Tamansuruh. In these three villages, there are angklung makers and musicians, and the people who are still playing it during their field ritual. Using community of Kemiren often present angklung art performances for tourists. Of all Using communities, only those living in Kemiren hold still strongly to the culture of Using, thus Kemiren was declared as an Using tourism village by the government of East Java Province in 1995 (Indiarti, 2015).

This study employed descriptive qualitative approach and based on the standard method of anthropology research (wide-ranged individual interviews, deep discussions, and participants observations) (Ripunjoy \& Indira, 2012; Choudhary et al., 2008). Data collecting was done through documentation, participant observations, and interviews (Bungin, 2012; Albuquerque et al., 2014a). The researcher acted as the instrument and the data collector. The documentation technique was conducted through reviewing literature of researches, journals, and books related to Using culture, especially angklung paglak. The participant observation was done by involving the researcher into the whole manufacturing process of angklung paglak, beginning from the bamboos logging until the harmonizing. The interview was done through direct communication 
with some informants. The interview was in the form of semi-structured individually and Focus Group Discussions (FGDs) (Choudhary et al., 2008).

Individual dept-interview was conducted through three stages namely preliminary, primary, and closing. The preliminary interview was carried out by introducing the researchers to the informants, explaining the research description generally, asking the informants' willingness or ensuring the importance of that informant's role in research that would be undertaken. In the primary interview, the research data collecting was done by semi-structured interview and directly observing the informant's activity; this interview was averagely conducted three times. In the close interview, the validity and reliability were conducted using cross-referenced and repeated information methods. Focus Group Discussion was executed twice by involving the main informant and recommendation-informant. The interview was conducted using interview guideline. There was an open discussion in every interview and it was recorded using a recorder as permitted by the informant and then the field journal was made.

The informants consist of main and recommended informants who were obtained through purposive and snowball sampling techniques (Bungin, 2012; Albuquerque et al., 2014b) . The purposive sampling technique was used to choose the main informants, while the snowball sampling technique was used to choose the recommended informants. The main informants were 61 and 57 years old-elders of Using in Kemiren Village. The recommendation-informants were the maker as well as the player of angklung paglak (local expert) and Using society. Based on the recommendation from both elders, the local experts are chosen from two people living in Kemiren Village and Tamansuruh Village and four people from Using society in Kemiren Village. According to the local expert from Tamansuruh Village, two other local experts were found namely one person is from Glagah Village, Glagah Sub-District and another one is from Mangir Village, Rogojampi Sub-District. The recommendation informants are 37-74 years old. All informants are the original residents of their village (they were born and still live in those villages). Based on the observation and preliminary interview results, the selected angklung makers are from Tamansuruh and Glagah Villages. The data analysis was done qualitatively. The data validity and reliability tests were done by using crossreferenced and repeated informations (Albuquerque et al., 2014b).

\section{Results}

Angklung paglak is played to amuse and motivate people who are harvesting their rice. Unluckily, the Using people now rarely play it when harvesting their rice. The angklungs were played instrumentally following the pentatonic slendro of Banyuwangi; it is different from the Sundanese angklung whose notes refer to the Western diatonic (Syaiful, 2015). The Using people call one piece of angklung as ancak angklung. One ancak contains 13-15 tones (13-15 bamboo tubes) which are connected using a strap and attached to a wooden bar (Fig. 2). The angklung set consists of two pieces, so that it needs two people to play; one as the main player and another one is the backing player (Fig. 3). Mostly, the angklung performance is followed by two kendang players; they use small size kendang. The most played songs are Lemar-lemir, Sekar Gadhung, Tetho Lelung, Gondoriyo, Kembang Jeruk, Lebak-lebak which are considered as old songs, while the new songs are Hoya-hoya, Jaran Ucul, Ojo Cilik Ati (Syaiful, 2015). 


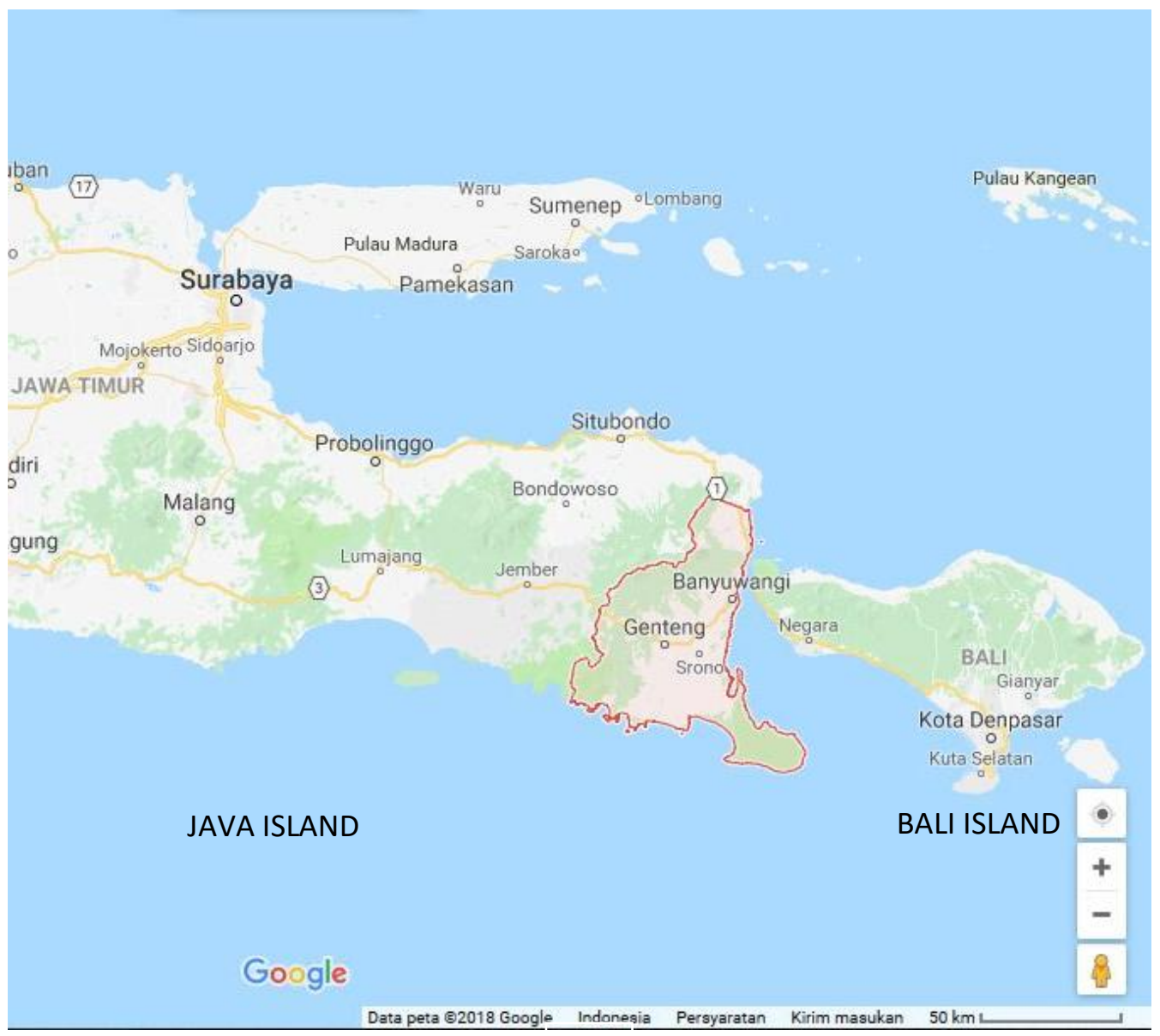

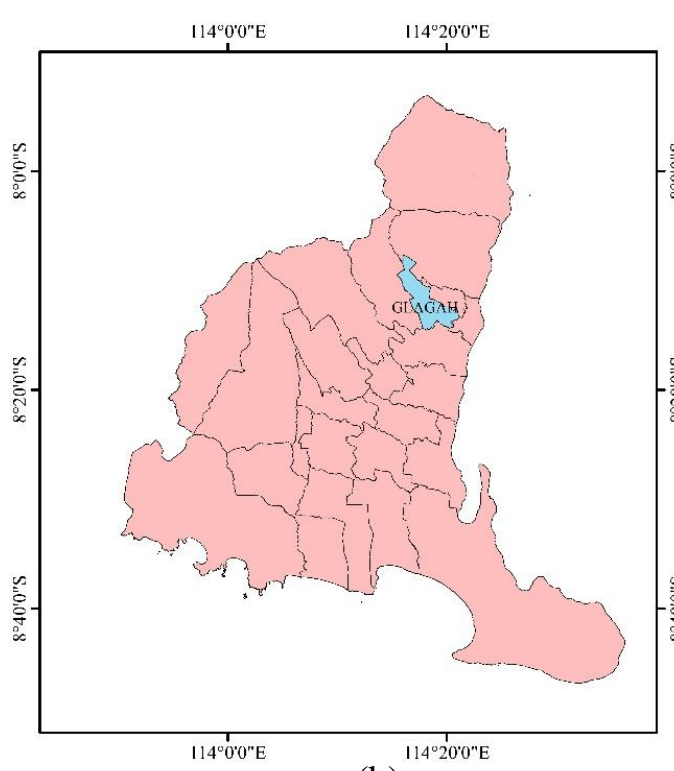

(b) (a)



(c)

Figure 1. Map of Banyuwangi Regency Location (a) Glagah Sub-District (b) Kemiren Village (c) 


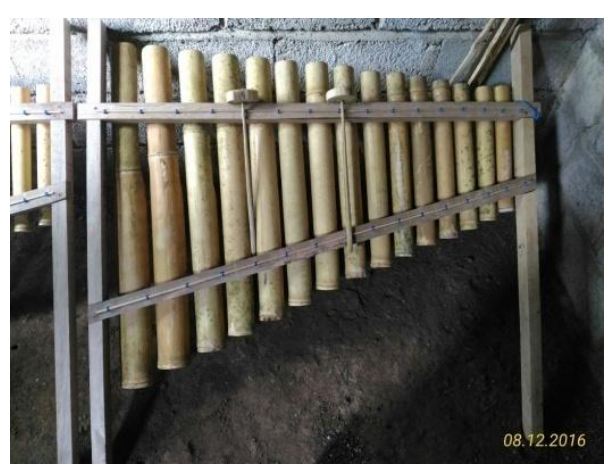

(a)

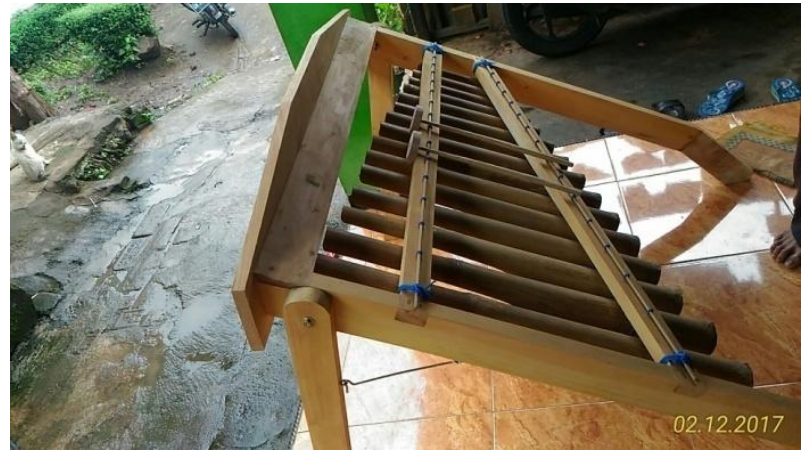

(b)

Figure 2. Photographs of angklung paglak. The original type of angklung paglak (a) and the modified one (b)

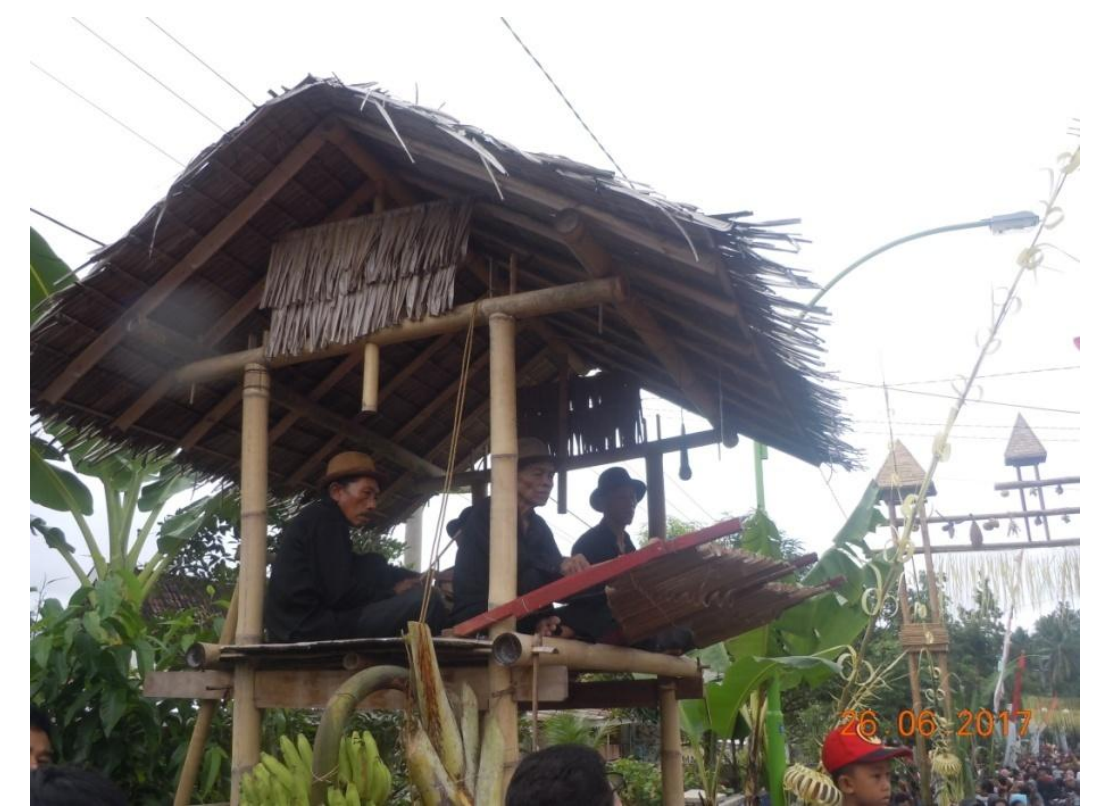

Figure 3. Angklung paglak performance in a custom ceremony. The musicians consist of two angklung players and two kendang players

Based on the participant's observation and interview, it is known that there were several stages in the process of angklung paglak manufacture, among others (1) bamboo culm selection, (2) bamboo logging, (3) drying, and (4) angklung harmonizing. The principle in its manufacture is to produce a quality angklung that has melodious and stable tone and unbreakable bamboo tubes. This principle is inherited by the ancestors.

\section{Bamboo culm selection}

Using people used benel (Gigantochloa atter) and ori (Bambusa arundinacea) bamboos to make angklung. The knowledge of both types of bamboo is originated by their ancestors hereditarily. The benel bamboo is used more frequently than the ori one due to the gentle sounds produced and the durable tone stability. Meanwhile, ori is used because of its high tone sound. However, there are some people also make a set of 
angklung from both benel and ori, in which tones 1-10 are from benel for producing bass sound, while the higher pitch tones 11-15 are from ori. The difference in selecting the type of bamboo used is related to everybody's interest in the resulted tone. Nevertheless, generally, people recognize that the sound of benel bamboo is the most tunable for angklung.

Angklung makers buy bamboo from bamboo clump owners and do not take the wild one. The bamboo is selected by the makers them selves since it is only they who know the characteristics of potential bamboos (Fig. 4a). The makers use bamboos of more than three years old with the erect culm. In this selection stage, there are two methods used to choose the culm; the first includes a bamboo that is more than three years old but still alive and the second includes a dead (dry) which they call the glagaran. The alive bamboo is characterized by its yellowish culm and over grown lichen, and is still leafy, coloured mostly yellow. While bamboo glagaran is characterized by the yellow and leafless culm. The maker who uses glagaran claims that based on his experience, it will not any further shrink making the sound stable (does not need to be harmonized frequently). Meanwhile, those who choose the alive culm also claim that the angklung tube does not easily break. Until today, both ways to select the culm are still utilized by the angklung makers that finally become the special characteristic of angklung. However, they should maintain the principle of producing a high-quality angklung (the sound is tunable and the tube does not easily break.

\section{Bamboo logging}

Using people believe that Pahing (one of the Javanese days) in August, September, and October is the best day to $\log$ a bamboo tree. However, the maker who uses glagaran may log in June up to October. Using people mark December up to February as a time when a shoot bamboo sprouts or rainy season comes. They believe that during the rainy days the bamboo "breastfeeds", this time the shoot bamboo sprouts, so Using people will not log the bamboo during those times. Based on the Using people's experience, the bamboo logged during the rainy days will be easily powdered due to the insects, the culm will get softer and cannot be used to make an angklung. Thus, the sound will be less melodious, unstable, and they need more time to dry the culm. The angklung makers are very selective in logging the bamboo and never choose the wild ones. There is a belief that bamboo growing near a river will need a longer time to dry, so they do not use such kind of bamboo. Bamboo that grows near a river produces less melodious sound, thus the tones tend to be unstable. Generally, they will test the potential tone of the culm by hitting it and listening to the sound produced.

\section{Bamboo drying}

Angklung makers who use live bamboo need to dry the bamboo before cutting it into pieces. After logging the bamboo culms, they will air dry the culm for about three months, without exposing it to the direct sunlight. Culm drying is done upright with the base position of the culm is below (Fig. $4 b$ ). Whenever they think that the culms are dry enough, the culms are then cut at every two nodes. Glagaran needs not drying. After logging glagaran culms, the maker cuts them at every two nodes and immediately continues with the harmonizing process.

The ancestors of Using people used to store the bamboo tubes on pogo (a rack made of a small sized bamboo which are arranged well). The Pogo is placed under the roof of their kitchen and above the stove, so that the bamboos were exposed to smoke. 
However, today's angklung makers prefer not doing so because the bamboo will turn black and it might influence the aesthetic. Based on their experience, there is no difference between bamboo stored on pogo or elsewhere.

\section{Harmonizing bamboo tones}

One of the bamboo tube sides is firstly cut with certain length using a buding (a type of a big knife). The bamboo tube is harmonized by shaving it with a knife to get the right tone according to its potential (Fig. 4c). Using people call the knife as ladeng lanang because it is usually used by men (Fig. 4d). This is the most difficult stage of all because they need to concentrate and be meticulous in listening to the tone produced. The setting of the first tone (the third low note) is the most important step in this stage. The meticulousness in listening to the tones is believed to be related to the art talent of the makers so that they can produce a melodious set of angklung (Fig. 4e). The bamboo tubes that have formed an angklung (13-15 tone) are perforated for the holes of strap. The fault position of the hole may affect the tone generated by the bamboo tubes. The strap used to tie and arrange angklung tubes is a plastic rope (Fig. 4f), but the Using ancestors used a rattan rope in the past. The simple form of the wood buttress without additional ornament eases the angklung players to bring it to the paglak. Nowadays, the shape of the wood buttress is made by request.

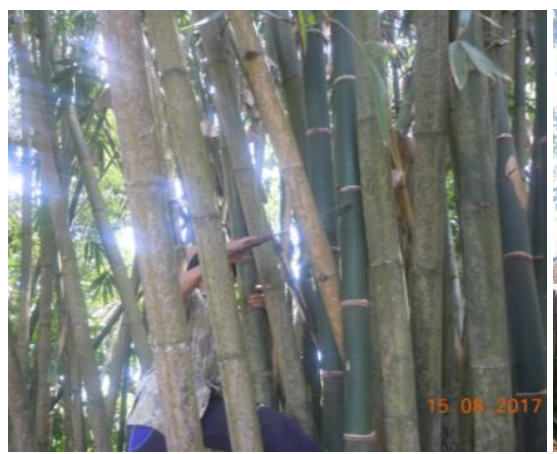

(a)

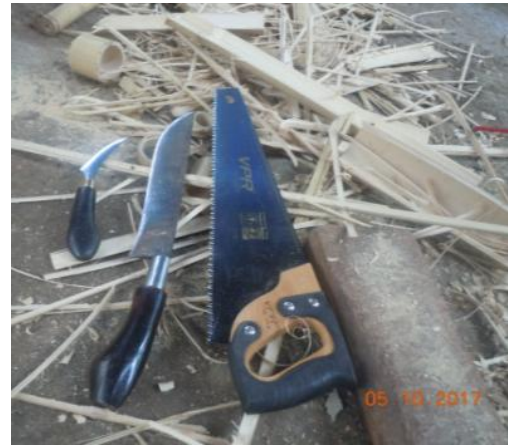

(d)

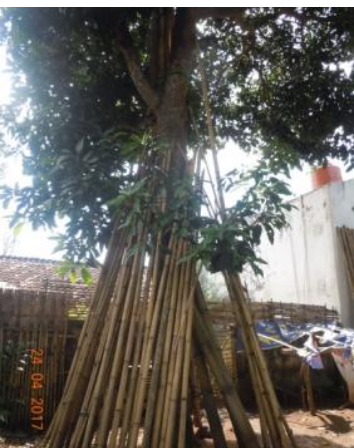

(b)

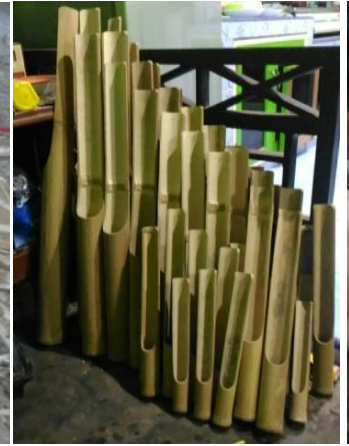

(e)

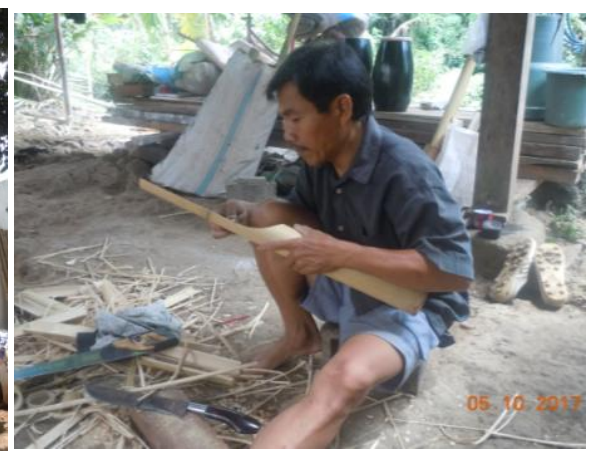

(c)

Figure 4. The angklung paglak manufacturing: Bamboo logging, done by the maker using saw and buding (a); Bamboo drying, the culm (alive bamboo) is air dried without being exposed to direct sunlight in upright position (b); Harmonizing angklung tones use ladeng lanang (a knife usually use by Using men), done by shaving the bamboo tube to get the right tone according to

its potential (c); traditional tool used to manufacture angklung (ladeng lanang to shave the bamboo tube, buding to cut bamboo's branch, saw to log and cut the bamboo into pieces) (d); a set of angklung paglak tubes as the result of angklung harmonizing (e); and the arrangement of angklung tubes using plastic rope at the wood buttress (f) 


\section{Discussion}

\section{The art of angklung paglak}

Nowadays, Using farmers who play angklung paglak or invite the musicians during harvest time are farmers who get a testament (weluri) from their ancestors. Weluri in Using can be assumed as messages or attitude inherited by the ancestors to their descendants. Now, angklung paglak is mostly played during art performances for tourism, traditional ritual such as Ider Bumi and Tumpeng Sewu in Kemiren, welcoming guests, and at event of Using family. Some musicians are often invited to perform in some international art performances. Angklung paglak is also sold and purchased by various buyers with different social background such as academicians, musicians, art lovers, and Using community outside of Banyuwangi. This is one of the reasons why angklung makers do not want to dry the bamboo on the pogo. Angklung selling also stimulates the makers to modify the wooden buttress to beautify the angklung, including the shape of buttress, added curvings and other ornaments.

\section{LEK in angklung paglak manufacture}

The ancestors of an ethnic community have proven to have done a local knowledgebased conservation (Tamalene and Al Muhdhar, 2017). The angklung manufacture is still based on weluri from ancestors. The principle of manufacturing a good angklung is still preserved. The angklungs are made carefully even though it takes time. Such weluri is considered as LEK of Using people since it includes belief, knowledge, and practices that are in line with the principle of natural resources management or conservation. Local practices are the result of experiment and observation among generation (Turner et al., 2000). The experience in managing bamboo has created a specific interaction pattern between Using people and the environment. This experience is descended from generation to generation. There is a small difference in the practice of angklung manufacture by the ancestors. Local practices are considered as a dynamic creativity and innovation mechanism (Slathia et al., 2016). The angklung makers available today have the descendant of the angklung makers. They said that since they were a child they often see their grandfathers/grandmothers play and make angklung so that they like angklung and are interested in making it as well. Their ancestors give weluri to make angklung in the form of belief, advice, guidance, taboo, knowledge, and practice to make angklung through oral transmission. The makers then learn to their ancestors (Fig. 5).

Their beliefs on logging bamboo culm on Pahing day and between August up to October are guidance for angklung maker. The time of collecting or harvesting a certain plant has a conservation value (Agize et al., 2013). Pahing in Indonesian means bitter, so bamboo which is logged on Pahing day is believed to be durable because insects will not gnaw it due to its bitter taste. They also mean that it will be their prayers. The belief has been proven through experiences since bamboo culms which are logged in other than August up to October will be easily powdered (gnawed by insect). Borer is pests of harvested bamboo so they will harm the bamboo. The borer species are including Dinoderus ocellaris, D. minutes, and D. brevis (Dransfield and Widjaja, 1995; DIJPEN, 2011). The starch content in the bamboo culm is the lowest during the dry season, thus, logging a bamboo culm during dry season will make the bamboo durable since the borer will not gnaw it because of the low starch inside (Razal et al., 2013). Using people will not log bamboo culm in December up to February because there is a taboo to log bamboo tree during the rainy season. They believe it will distort the "breastfeeding time" 
(sprouting process). This belief helps preserve the bamboo regeneration. Local belief in something taboo plays a role in environmental preservation because it makes people beware in resources utilization (Tamalene et al., 2014), and has preserved various kinds of species (Gavali and Sharma, 2004). Bamboo logging during a shoot sprout will destroy the shoot itself and influence the bamboo regeneration (Razal et al., 2013).

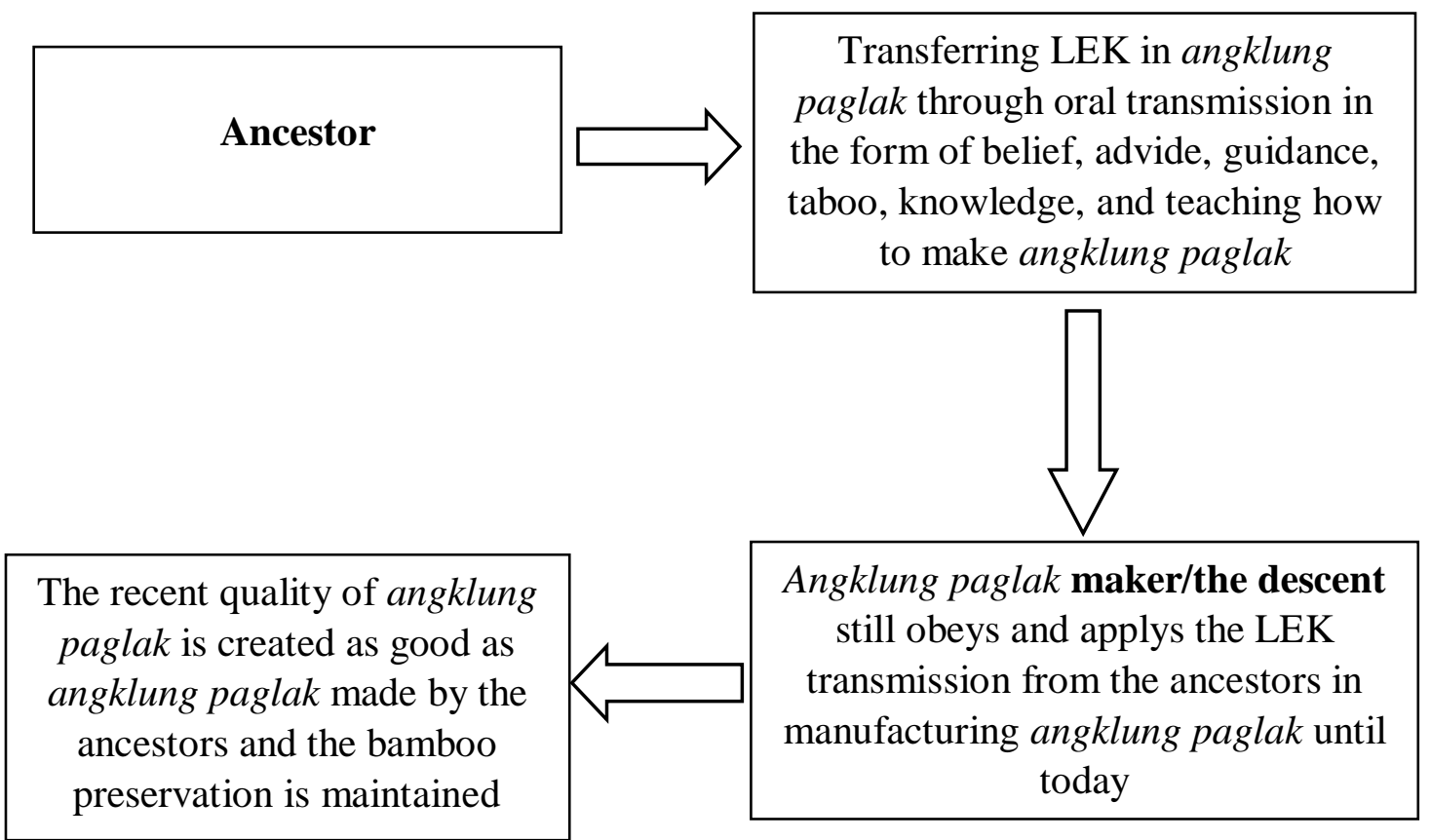

Figure 5. Process of LEK transmission in angklung paglak making

The knowledge of bamboo species (benel and ori) and criteria of suitable culm as the angklung material are precious knowledge, so as the process of its manufacture. Local knowledge about benel and ori as angklung materials will lead to the preservation of these bamboo varieties. The difference between the former and today's angklung manufacture becomes the reflection of LEK evolutionary in which new knowledge may exist replacing the previous knowledge based on experiences or trial of a generation (Sunaryo and Joshi, 2003). Such difference in knowledge includes the difference in selecting the bamboo age, drying process, and the variation of bamboo in one ancak angklung. The most important thing is the consistency in making melodious angklung, stable tones, and durable or unbreakable bamboo tubes.

The high demand of angklung makes the bamboo stock dropped. Therefore, the local practice and wisdom which is possible to be done by the makers is to log as many bamboo culms as possible in August up to October for stocks. Yet, selective logging is still practiced by Using people. They only log the potential bamboo, with appropriate age (more than three years old) and erected culm. The makers, who choose glagaran bamboo, will not make angklung of carelessly chosen bamboo to fulfill the demand. They sometimes stock the angklung which are ready to be sold. If there is a request and they run out of bamboo, they will ask the customer to wait. They do not want to disappoint their customers because of its quality.

The bamboo conservation practices can be seen during the whole process of angklung manufacturing, beginning from the bamboo selection, bamboo drying, and 
angklung harmonizing. The logging day and the selective felling which are not done when shoot bamboos are sprouting are the practice of bamboo management by considering the bamboo preservation. The selective felling can conserve the bamboo and its reproduction (Dransfield and Widjaja, 1995), while clear felling of bamboo clumps will affect the number of sprouts and the height of bamboo (Nath et al., 2009). The selective felling which is done by logging only a potential bamboo is a practice of showing respect to the nature, i.e. the right of bamboo to live and grow naturally. Meanwhile, drying the bamboo culm is done by for a particular period without additional substances. Angklung makers do not manipulate the bamboo culm and only manage it naturally. The culm is only cut into several tubes, which are harmonized regarding to the potential tones until get melodious tones. Briefly, the procedure to make angklung includes four stages (Table 1).

Table 1. Stages of Angklung making

\begin{tabular}{|c|c|c|}
\hline No. & Stages of Angklung Making & Activities \\
\hline 1 & Bamboo culm selection & $\begin{array}{l}\text { - The type of bamboo used: } \\
\text { (1) Benel (Gigantochloa atter): produced gentle } \\
\text { sounds } \\
\text { (2) Ori (Bambusa arundinacea): produced high } \\
\text { tone sound } \\
\text { - The type of benel is the most frequently used } \\
\text { bamboo } \\
\text { - The age of bamboo: more than three years old } \\
\text { bamboos with the erect culm. Two methods used } \\
\text { (1) alive bamboo: it needs a drying process firstly } \\
\text { (2) dead (dry) bamboo: it does not need the drying } \\
\text { process; it can be directly harmonized }\end{array}$ \\
\hline 2 & Bamboo logging & $\begin{array}{l}\text { - A belief that Pahing (one of the Javanese days) in } \\
\text { August, September, and October is the best day to } \\
\text { log bamboo for angklung } \\
\text { - Do not log bamboo during sprouting time in rainy } \\
\text { season (a taboo) } \\
\text { - Dead bamboo (glagaran) can be logged since June to } \\
\text { October }\end{array}$ \\
\hline 3 & Bamboo drying & $\begin{array}{l}\text { - Alive bamboo is air-dried at the upright position } \\
\text { where the base part is in the bottom for about three } \\
\text { months }\end{array}$ \\
\hline 4 & Angklung harmonizing & $\begin{array}{l}\text { - One of the bamboo tube sides is partly cut } \\
\text { - That part is shaved with a knife (ladeng lanang) to } \\
\text { get a right tone } \\
\text { - Every tube is perforated for the rope hole } \\
\text { - Arranging the the bamboo tube at the wood buttress } \\
\text { is started from the low to the high tones using plastic } \\
\text { rope }\end{array}$ \\
\hline
\end{tabular}

The angklung maker does not log wild bamboo at a riverside or forest. Whereas, logging the wild one will not be as costly as when logging the clumps from the bamboo farmers. One ancak angklung needs 6-8 bamboo culms since each culm might produce 
different potential tones. The angklung makers mostly buy bamboo from clumps at farmer's field or garden. Meanwhile, the bamboo management done by the bamboo farmers in Kemiren Village includes two things namely planting and preserving the bamboo (Table 2). Home gardens play an important role in conservation and management of the sustaining natural resources species (Agize, 2013). The decision to buy bamboo culm is considered as a conservation practice for it preserves the wild bamboo life.

Table 2. Bamboo management

\begin{tabular}{c|l|l}
\hline No & Type of Management & \multicolumn{1}{c}{ Technique of Management } \\
\hline 1. & Bamboo planting & $\begin{array}{l}\text { The 1-2 years old bamboo is cut with the height about } 1 \\
\text { meter from the ground } \\
\text { The bamboo with its rhizome (Using people call it } \\
\text { bongkotan) are taken; it is then planted in the place they } \\
\text { want } \\
\text { The new sprouts (different from the shoot) will grow close } \\
\text { to the stem base or rhizome while the stem is weathered } \\
\text { over time }\end{array}$ \\
\hline 2. & Preservation & $\begin{array}{l}\text { People apply selective felling to preserve the bamboo to } \\
\text { keep the productivity } \\
\text { The three years-bamboo will be cut/harvested } \\
\text { The harvesting is undertaken out of rainy season (out of } \\
\text { sprouting period) }\end{array}$ \\
\hline
\end{tabular}

Unfortunately, there is a belief in Using community that angklung makers must be the descendant of the previous angklung makers. Using people believe that only those who descent the blood of angklung makers or those who have art talent are capable to make melodious angklungs. These people are considered to have diligence and capability in listening to tones, and they must inherit this ability from their ancestors. This ability causes other people who want to learn to make an angklung less confident. Besides, the instructor or the angklung maker will also doubt the students' perseverance in manufacturing angklung, since they have to be very patient in listening and finding the correct tone.

Angklung paglak is a symbol of cooperation in farming of Using community. This art is disappearing within the decreasing cooperation tradition (ngrasah) in field, even though it is not reducing the social interaction between Using people. The cooperation in harvesting time no longer exists since they harvest the rice by using a sickle and a rice mill. The rice is directly sold in field, so the process of harvesting runs quickly. It is different from the past, where people used traditional finger-bladed knife (aniani/gampung) therefore the harvest time took several days. Angklung paglak performance which was done formerly in harvest time is no longer practiced today. A local tradition has an important role in conserving biodiversity. A local tradition that is still done by a community may preserve the conservation practices related to that tradition (Tamalene and Al Muhdhar, 2017). The biodiversity conservation is appropriate when it applies cultural value and religion approach compared to constitution and law regulation (Hongmao et al., 2002). 


\section{Conclusion}

In brief, angklung paglak is one of the cultural products of Using community as the expression of farming culture. The process of angklung manufacturing consists of several stages: bamboo selection, logging, drying, and angklung harmonizing. Each process is considered as a system of local knowledge or LEK which includes belief, knowledge, and practices of managing bamboo. Local knowledge in angklung making including selecting benel (Gigantochloa atter) and ori (Bambusa arundinacea) as angklung materials, age of bamboo (more than three years old), best month for logging in August up to October, and air drying the bamboo without exposing it to the direct sunlight in upright position. The belief on a particular day that is on Pahing day and a taboo for logging in December up to February may affect to the time of bamboo logging. The selective felling practice by choosing only potential bamboo, buying it rather than logging the wild one also contribute to the bamboo preservation. The bamboo drying, which is done in order to prevent borer to gnaw the bamboo starch, is also done without any manipulation and chemical substances addition. This reflects ecological human characteristics. Angklung making teaches people to preserve and live in harmony with the nature. The perseverance in harmonizing angklung also contains value respect to the nature, for what it has given to humans.

Acknowledgements. The authors greatly appreciate all informants, especially Mr. Andori and Mr. Ardi (the angklung makers). The deep gratitude is also dedicated to Mr. Purwadi and Mr. Suhaemi as the elders of Using community in Kemiren Village, Banyuwangi.

\section{REFERENCES}

[1] Agize, M., Demissew, S., Asfaw, Z. (2013): Indigenous knowledge on management of home gardens and plants in Loma and Gena Bosa Districts (Weredas) of Dawro Zone, Southern Ethiopia: plant biodiversity conservation, sustainable utilization and environmental protection. - International Journal of Sciences: Basic and Applied Research (IJSBAR) 10(1): 63-99.

[2] Albuquerque, U. P., Ramos, M. A., de Lucena R. F. P., Alencar, N. L. (2014a): Methods and Techniques Used to Collect Ethnobiological Data. - In: Albuquerque, U. P., Cunha, L. V. F. C., Lucena, R. F. P., Alves, R. R. N. (eds) Methods and Techniques in Ethnobiology and Ethnoecology. E-book. Humana Press, New York.

[3] Albuquerque, U. P., Lucena R. F. P., Lins Neto, E. M. F. (2014b): Selection of Research Participants. - In: Albuquerque, U. P., Cunha, L. V. F. C., Lucena, R. F. P., Alves, R. R. N. (eds) Methods and Techniques in Ethnobiology and Ethnoecology. E-book. Humana Press, New York.

[4] Badan Pusat Statistik Kabupaten Banyuwangi. (2015): Statistik daerah Kecamatan Glagah 2015.

[5] Berkes, F., Colding, J., Folke, C. (2000): Rediscovery of traditional ecological knowledge as adaptive management. - Ecological Applications 10(5): 1251-1262.

[6] Bungin, B. 2012. Penelitian Kualitatif: Komunikasi, Ekonomi, Kebijakan Publik, dan Ilmu Sosial Lainnya. - Edisi kedua. Jakarta: Kencana Prenada Media Group.

[7] Chaiphar, W., Sakolnakorn, T. P. N., Naipinit, A. (2013): Local wisdom in the environmental management of a community: analysis of local knowledge in Tha Pong Village, Thailand. - Journal of Sustainable Development 6(8): 16-25. 
[8] Choudhary, B. I., Katewa, S. S., Galav, P. K. (2008): Plant in material culture of tribal and rural communities of Rajsamand District of Rajasthan. - Indian Journal of Traditional Knowledge 7(1): 11-22.

[9] DIJPEN Kementerian Perdagangan Republik Indonesia. (2011): Menggali peluang ekspor untuk produk dari bambu. - Warta Ekspor 002(12): 3-13.

[10] Dransfield, S., Widjaja, E. A. (eds). (1995): Plant Resource of South-East Asia. Backhuys Publisher, Leiden.

[11] Gadgil, M., Berkes, F., Folke, C. (1993): Indigenous knowledge for biodiversity conservation. - Ambio 22(2/3): 151-156.

[12] Gavali, D., Sharma, D. (2004): Traditional knowledge and biodiversity conservation in Gujarat. - Indian Journal of Traditional Knowledge 3(1): 51-58.

[13] Hongmao, L., Zaifu, X., Youkai, X., Jinxiu, W. (2002): Practice of conserving plant diversity through traditional beliefs: a case study in Xishuangbanna, southwest China. Biodiversity and Conservation 11: 705-713.

[14] Indiarti, W. (2015): Kajian mengenai Desa Kemiren sebagai Penyangga Tradisi dan Kearifan Lokal Masyarakat Osing. - In: Anasrullah, S. M. (ed.) Jagat Osing: Seni, Tradisi \& Kearifan Lokal Osing. Rumah Budaya Osing, Banyuwangi.

[15] Jasmine, B., Singh, Y., Onial, M., Mathur, V. B., (2016): Traditional knowledge systems in India for biodiversity conservation. - Indian Journal of Traditional Knowledge 15(2): 304-312.

[16] Keraf, A.S. (2002): Etika Lingkungan. - Kompas, Jakarta.

[17] Koentjaraningrat. (2015): Pengantar Ilmu Antropologi. - Rineka Cipta, Jakarta.

[18] Martin, G. J. (2001): Ethnobiology and ethnoecology. - Encyclopedia of biodiversity 2: 609-621.

[19] Nath, A. J., Das, G., Das, A. K. (2009): Traditional knowledge base in the management of village bamboos: a case study in Barak Valley, Assam, Northeast India. - Indian Journal of Traditional Knowledge 8(2): 163-168.

[20] Razal, R. A., Bantayan, R. B., Delgado, T. S., Elec, J. A. (2013): Bamboo poles for engineered-bamboo products through improved clump management and harvesting: lessons for the Philippine. - Ecosystems \& Development Journal 4(1): 39-49.

[21] Ripunjoy, S., Indira, B. (2012): Indigenous knowledge and bioresource utilization among the Tai-Khamyang of Assam, North East India. - International Research Journal of Biological Sciences 1(7): 38-43.

[22] Ruiz-Mallén, I., Domínguez, P., Calvet-Mir L., Orta -Martinez, M., Reyes-García, V. (2012): Applied research in ethnoecology: fieldwork experiences. - Revista de Antropología Iberoamericana 7(1): 9-30.

[23] Saputro, A. B., Purwadi, A., Marhaedi, S. (2015): Membaca Tradisi Pertanian Masyarakat Osing: Tata Cara Pengolahan, Ragam Ritual, Ekspresi dan Makna Budayanya. - In: Anasrullah, S. M. (ed.) Jagat Osing: Seni, Tradisi \& Kearifan Lokal Osing. Rumah Budaya Osing, Banyuwangi.

[24] Slathia, P. S., Sharma, B. C., Paul, N., Kumar, R., Gupta, S. K. (2016): Traditional water conveyance modes, their management and use in Udhampur district of Jammu and Kashmir. - Indian Journal of Traditional Knowledge 15(3): 503-508.

[25] Sunaryo, Joshi, L. (2003): Peranan Pengetahuan Ekologi Lokal dalam Sistem Agroforestri. - World Agroforestry Centre (ICRAF), Bogor.

[26] Syaiful, M. (2015). Angklung Paglak dan Nilai-nilai Kehidupan Masyarakat Desa. - In: Anasrullah, S. M. (ed.) Jagat Osing: Seni, Tradisi \& Kearifan Lokal Osing. Rumah Budaya Osing, Banyuwangi.

[27] Tamalene, M. N., Al Muhdhar, M. H. I., Suarsini, E., Rochman, F. (2014): The practice of local wisdom of Tobelo Dalam (Togutil) tribal community in forest conservation in Halmahera, Indonesia. - International Journal of Plant Research 4(4A): 1-7.

[28] Tamalene, M. N., Al Muhdhar, M. H. I. (2017): Local knowledge of management system of forest ecosystem by Togutil ethnic group on Halmahera Island, Indonesia: traditional 
utilization and conservation. - International Journal of Conservation Science 8(3): 497508.

[29] Turner, N. J., Ignace, M. B., Ignace, R. (2000): Traditional ecological knowledge and wisdom of aboriginal peoples in British Columbia. - Ecological Application 10(5): 12751287.

[30] Vandebroek, I., Reyes-García, V., Albuquerque, U. P., Bussmann, R., Pieroni, A. (2011): Local knowledge: who cares? - Journal of Ethnobiology and Ethnomedicine 7(35): 1-7. 